\title{
Mexican birds use according to environmental officers
}

Blanca Roldán-Clarà1, 2, *, Xavier López-Medellín³, Claudia Leyva1, Nelly Calderón de la Barca1, Ileana Espejel ${ }^{11}$

\begin{abstract}
Birds are used in México for subsistence income and have traditionally been part of local cultural heritage. A group of people called pajareros are required by law to apply for permits for harvesting and selling birds, which are authorized by Mexican environmental and wildlife government officers mostly for subsistence use. While environmental manager officers interact with stakeholders as part of their work, how they actually interrelate with pajareros and make final decisions remains unclear. Therefore, we describe regulation of bird use in Mexico, analyze criteria applied, and provide the opinions of the four key officers involved in natural resource management obtained in open interviews held during 2012. Officers have a stereotyped view about pajareros and a close, sometimes conflicting relation with them, express good knowledge of social-environmental conflict related with songbirds, and decide songbird harvest rates based on the three pillars of sustainability, but prioritizing environmental laws over social needs.
\end{abstract}

Keywords: Levels of Extraction, Songbirds, Stakeholders, Sustainable use of Natural Resources, Traditional Commercial Activities

\footnotetext{
1 Universidad Autónoma de Baja California (UABC). Carretera Transpeninsular Ensenada - Tijuana No. 3917. Colonia Playitas C.P. 22860. Ensenada, Baja California, México.

2 Current adress: Universidad de Occidente. Av. del Mar 1200, Col. Flamingos, 82149 Mazatlán, Sinaloa, México.

${ }^{3}$ Centro de Investigación en Biodiversidad y Conservación, Universidad Autónoma del Estado de Morelos. Avenida Universidad 1001, Chamilpa, 62209 Cuernavaca, Morelos, México.
}

* $\quad$ E-mail address: BRC (blancamar@gmail.com),XLM ( xImedellin@uaem.mx), CL (cleyva@uabc.edu.mx), NCB (nellycalderon@uabc.edu.mx), IE (ileana.espejel@uabc.edu.mx)

\section{INTRODUCTION}

The close relationship that humans have with birds is ratified by hundreds of international and Mexican studies (e.g. Vásquez-Dávila 2014). This relationship is based on the different uses and meanings that birds can have for humans, from food (e.g. Bezerra et al. 2012) and medicine (e.g. Bezerra et al. 2013; Alves and Rosa 2013), to therapy and company (e.g. Alves and Souto 2015). Song and ornamental birds (SOB)-including parrots, cardinals, seedeaters, mockingbirds, and other songbirds-are the most exploited of all traded animals and plants worldwide (Iñigo- 
Elias and Ramos 1991, Alves 2012a; Bush et al. 2014). Birds are customarily kept in captivity as pets (Iñigo-Elias and Ramos, 1991) for their beauty, color, songs, and ability to imitate words (Gobbi et al. 1996; Alves 2012b).

The use of birds as pets is a common practice all over the world, from Asia (e.g Sumatra: Burivalova et al. 2017; Indonesia Kristiano and Jepson 2011, China: Li \& Jiang 2014), Africa (e.g. Malawi: Dowsett-Lemaire et al. 2015; Williams et al. 2013) Europe (e.g. South and Wyatt 2011), America (e.g. Syker et al. 2006; Blundell and Mascia 2005) and of course Latin America. In Latin America we find research in Costa Rica (Drews 2001), Venezuela (Marín-Espinoza et al. 2011), Mexico (e.g. Roldán-Clarà et al. 2017), Bolivia and Peru (e.g. Pires et al. 2016) but Brazil is the main country were research is done about ethno-ornithology and the use of birds as pets (e.g. Alves 2012b; Silva Souto et al. 2017).

However, due to the main threats globally faced by birds -including habitat destruction and trade (Reuter and Mosig 2010), and because only a fraction of the traded birds are reproduced in captivity (American Ornithologist' Union, AOU 1991), bird extraction from nature must be regulated. Regulation may be at international level through the Convention on International Trade in Endangered Species of Wild Fauna and Flora (CITES) and mainly by import, export and border controls, or at national scale through national laws. Most of the studies related to ethno-ornithology and bird trade are based on CITES data (e.g. Blundell and Mascia 2005; Bush et al. 2014, Lenzen et al. 2012) and in Latin America are based on list of species used (e.g. RoldánClarà et al. 2014). For example Alves and collaborators $(2010,2013)$ and Licariao and collaborators (2013) listed bird species used as pets in East and northeast of Brazil. Therefore, very few international and Latin America studies explore how bird trade is regulated at national level. SOB were traditionally used and traded in Mexico since before the Spanish conquest (Sahagún 1969), its commerce currently having national coverage (Reuter and Mosig 2010). The stakeholders involved in traditional SOB trade are people and organizations from various sectors including direct users, local and international governmental institutions, nongovernmental organizations (NGO), and scholars (Roldán-Clarà 2015). Governmental officers representing the institutions responsible for regulating the activity are key elements in management and trading of SOB. Regulation began in the 1970's, the most important current laws monitored and applied by the Ministry of Environment and Natural Resources (Semarnat, by its Spanish acronym) being the General Law of Ecological Equilibrium and Protection of the Environment (LGEEPA, by its Spanish acronym, 1988) and the General Law of Wildlife (LGVS, by its Spanish acronym, 2000), but the legal framework in this area comprises 14 national and international legal texts including laws, norms, international agreements, and law regulations, among others (Roldán-Clarà et al. 2014).

Article 83 of the LGVS states that extractive use of natural resources, such as SOB, "[...] requires prior authorization from the Ministry of Environment and Natural Resources establishing harvest rates and temporality." Likewise, Article 87 of the LGEEPA dictates, "the use of wild animal and plant species for economic activities may be authorized when [...] the harvest rate is less than the natural renewal of populations."

The two most important governmental institutions involved in SOB use are the 
General Wildlife Office (DGVS in its Spanish acronym) from Semarnat, and the interministerial National Commission for the Knowledge and Use of Biodiversity (CONABIO, by its Spanish acronym). DGVS operates the legal instruments for determining catchable bird species, capture seasons, and harvest rates. CONABIO provides technical data and makes recommendations based on monitoring and evaluation of bird populations. The Federal Attorney for Environmental Protection (PROFEPA by its Spanish acronym) is responsible for inspecting and enforcing environmental laws and regulations, also being involved in SOB use and trade.

Based on this legal framework, the DGVS grants permits for capturing and selling SOB in two modalities: permits for Management Units for the Conservation of Wildlife (UMAs in its Spanish acronym), and subsistence permits. The UMAs system is a national strategy for wildlife use and conservation (Semarnat 1997), supposedly allowing the implementation of in situ conservation and harvesting of wildlife. Each UMA has a management plan approved by the DGVS describing its objectives and the conditions of the area (Avila-Foucat and PérezCampuzano 2015; Weber et al. 2006). The subsistence permits are granted to associations of bird catchers and vendors organized and registered by Semarnat (López-Medellín, and Iñigo-Elias, 2009) or to their members (Cruz-Romo and Olivera de Ita 2011). People whom for generations have been using SOB for cultural and economic reasons -known as pajareros- often belong to these associations. Article 92 (included in Title VII, Chapter II: Use for Subsistence) of the LGVS defines use for subsistence as: "Local people who use specimens, parts or derivatives of wildlife for consumption or sale, for total or partial satisfaction of basic needs directly related to food, housing, and health, as well as needs of financial dependents". It is important to mention that UMAs permits are the more recently implemented modality, that their areas are mostly privately owned, and that there are a few SOB UMAs (López-Medellín, and IñigoElias 2009), while subsistence permits are older and pajareros do not own private land.

Legal concepts are vague, for example, the LGVS conceives harvest rate as "the quantity of specimens, parts or derivatives that can be removed within a specified area and time period, so that the maintenance of the resource and its productive potential are not affected in the long term." But, what does long term means? Section II of Article 15 of the LGEEPA mentions "ecosystems and their elements should be used in a way that optimal and sustainable productivity are ensured, according with their balance and integrity", and Section VII states "the use of renewable natural resources must be in a way that it ensures the maintenance of their diversity and renewal." But the meanings of "sustainable" and "renewal" remain imprecise.

Wildlife management aims to create, facilitate, regulate and/or prohibit interactions that humans have with wildlife. Much of the work of the environmental managers is to interact with stakeholders. There are different approaches used by wildlife managers to solve problems and to define actions: authoritarian, passive-receptive, inquisitive, negotiation, delegatory and tutorial (Mortenson and Krannich, 2001). Given the number of legal documents on this subject, it is expected that the decisionmaking system follows an authoritarian approach, which is characterized by exercising formal sovereign authority. What seem clear are the difficulties for operationalizing these laws. Emerging 
questions are how do DGVS officers apply the copious legal framework for making decisions about SOB use and management, and how do they interrelate with permit holders and users of SOB?

In the case of Mexico DGVS officers are key informants (Reed, Henderson and Mendis-Millard 2013; Albuquerque et al. 2014a) because they hold the legal tools for ruling wildlife management and decisionmaking when granting harvest permits, and CONABIO officers are crucial because they provide technical data for deciding which species can be captured and at what harvest rates; harvest rates are relevant since they provide information for estimating if use of the resource is actually made in a sustainable and equitable manner (Johnson et al. 2012; Toledo 2003).

Because of the above-mentioned reasons, we interviewed the officers involved in regulation of SOB extraction permits in order to understand the process of decisionmaking regarding use of $\mathrm{SOB}$. We found that in Mexico -a large country with high bird biodiversity (Navarro-Sigüenza et al. 2014) a limited number of officers from DGVS and CONABIO (the two government institutions responsible for regulating this activity) are in charge of the regulation process. Therefore, the aim of our paper is to examine the management of the song and ornamental bird trade in Mexico according to Mexican wildlife officers. The opinions of four interviewees we present here were quintessential in providing critical information about the functioning of the regulation of subsistence use SOB and the criteria used for determining harvest rates. This paper is the first research approach to SOB use in Mexico and forms part of a comprehensive diagnosis (Roldán-Clarà 2015).

\section{METHODS}

We used qualitative research techniques that render descriptive data (Milers 1994). We used judgment sampling because we focused on a small group of people based on their experience and knowledge (Albuquerque et al. 2014a). Four semistructured interviews (Taylor, and Bogdan 1984; Miles, and Huberman 1994) with open ended questions (see annex 1) were conducted on April 2012 with four high-level DGVS and CONABIO officers (active or inactive) with over 10 years of experience in SOB management. These respondents were chosen because they were considered as the universe of the potential interviewees and therefore they represented the $100 \%$ for the whole population, because they were the most important in decision-making while performing our research, therefore, the sample size is representative and the strength of the generalizations made in the study are validated (Albuquerque et al. 2014b). Three interviews were conducted in the interviewee's workplaces and the other one in a neutral setting, and we followed the general recommendations mentioned by Albuquerque and collaborators (2014c). Each interview lasted approximately one hour and were recorded and transcribed. We follow the Code of Ethics from the International Society of Ethnobiology (2006) so all information was obtained with the participants' informed consent.

Content analysis was qualitative inductive. Categories were formulated step by step from the text of interviews, excluding old categories and formulating new ones (Andréu-Abela 2001). The analysis was descriptive to identify and catalogue the empirical reality of the interviews through the definition of categories or classes of its elements. The categories chosen through 
thematic units (Piñuel-Raigada 2002) were: 1) characteristics of SOB use, 2) determination of harvest rates, 3) relationship between government officers and other stakeholders, 4) officers' perception of their work, 5) problems detected, and 6) most controversial issues regarding SOB use.

\section{RESULTS AND DISCUSSION}

The four interviewees concur on many of their narrative and some of their testimonies have repeated information, therefore, we might consider saturation of information (Hernández Sampieri et al. 2007) with the four interviews.

\section{Characteristics of SOB use}

According to the interviewed Mexican officers the registry of bird catchers includes between 700 and 800 members $^{1}$, and some 4,000 pajareros throughout the country. The Wildlife Conservation Program and Productive Diversification in the Rural Sector, 1997-2000, (page 84) accounts for 563 registered bird catchers, while Johnson Walters, and Scott (2012) estimate that figure in around 600. Discrepancies may be due to the increase in the number of pajareros, or to unreliable registering.

Officers mentioned pajareros capture birds seasonally, but sell them throughout the year, and that DGVS provides bird bands, as mentioned in the still existing Procedure Manual (DOF 1998), because all
SOB used in Mexico must be marked. They justify SOB use for subsistence purposes based on three reasons: poverty, as indicated by the LGVS in its article 51 , it is a traditional cultural activity, and it is a familiar or inherited cultural activity. FernandesFerreira et al. (2012), also recognized the cultural traditions as the root for the use of wild birds in the rural inhabitants in the Northeast Brazil, and Melink et al. (1988) described the deep tradition of the use of cage birds in San Luis Potosí, Mexico. Moreover, Roldán-Clarà et al. (2017) report the deep relation between family members and the use of birds as pets in Central Mexico.

In order for pajareros to obtain a subsistence permit they must prove: they have been dedicated to the activity for years, the activity generates an income for their families, and they are residents of the locality in which SOB are captured, as mentioned in Article 107 of the LGVS. After the pajareros meet these requirements, officers deliver them an application with their photograph, in accordance with the Procedure Manual related to the conservation, management, and sustainable use of wild fauna and flora and other biological resources (1998), and proof of address. Subsistence use of SOB does not need of a management plan ${ }^{2}$, only requiring the consent of land-owners for capturing SOB, as stated in the LGEEPA (1988) and in the Manual (DOF 1998), and submitting a report at the end of the season. That report contains general information about the bird

\footnotetext{
1 The Procedure Manual for Authorizations, Permits, Registration, Reports and Notices (Procedure Manual, 1998) mentions that the Registry of Use of Song and Ornamental Birds (raco in its Spanish acronym) is the administrative instrument from which the Ministry integrates the National Registry of SOB users. The LGVS and its regulation omit mentions about the register of bird catchers.

2 The management plan is "the operating technical document of the Management Units for the Conservation of Wildlife subjected to approval by the Ministry (Semarnat), that describes and plans activities for the management of specific wildlife species and their habitats and sets targets and indicators of success depending on the habitat and populations" (Igvs). Currently, the Type Management Plan (pmt in its Spanish acronym) of SOB is available. In accordance with the lgvs standards published in 2006, the pmt is "elaborated by the Ministry to standardize the development of conservation activities, management and sustainable development of wildlife species or group of species that might require".
} 
catcher, general capture data, and total number of authorized and captured specimens $^{3}$. Each bird catcher is authorized to harvest approximately 270 birds of 30 species (10-15 birds per species). The permit is granted free of cost and for exclusive personal use. It mentions that exotic birds (House Sparrow, Passer domesticus; European Starling, Sturnus vulgaris and Monk Parakeet, Myiopsitta monachus) can be captured "unlimitedly," but complying with specimen marking ${ }^{4}$. Even bird species included in the $\mathrm{NOM}-059^{5}$ can be harvested despite the increased pressure on these birds relative to others -as in the cases of the Brown-backed Solitaire (Myadestes occidentalis), the Slate-colored Solitaire (Myadestes unicolor), and the Painted Bunting (Passerina ciris). The two above-mentioned species of Solitaire are in great demand, as other authors have found in Mexico (Gómez-Álvarez et al. 2005; De la Cruz Montesino et al. 2014), have restricted distributions, very specific habitat requirements, their population sizes are difficult to be estimated, and are protected (NOM-059). In addition, it is a common perception that their populations are under extreme pressure by the destruction of their habitat. With regard to the Painted Bunting, they mention that for 15 years the harvest rate has not been determined because the continental population data indicate that the species is declining, so an interviewee emphasized, "we are meticulous about this species."

Although permits do not establish a sex ratio there are several species in which the number of captured birds is based on sex because, in general, male birds are showier, sing better, and are therefore more desirable. There are reports of more males than females being caught (Cruz-Romo and Ita Olivera 2011), which officers consider a possible problem for bird populations. Ethnoonithological literature points that this situation is similar in others locations (see Fernandes-Ferreira et al. 2012; Alves et al. 2012).

According to an interviewee, pajareros are organized in SOB capturing groups (see also Roldán-Clarà et al. 2017), and some bird catchers and sellers belong to four associations in Mexico. It is interesting to note that we did not find other traditional bird trader organizations in Latin American countries but exist in countries like Spain (see Belda et al. 2012) and Indonesia (see Jepson et al. 2011). Probably it is related by the national regulation framework. In Mexico these organizations apply for capturing quotas for their members, and although it is uncertain how they were formed, each one has a leader that manages permits, performs procedures in Mexico City, and has power to negotiate. One of the interviewees considered associations have a hierarchical structure and are political forces used as pressure groups in the process of SOB permits. Officers describe pajareros in various ways according to economic condition, cultural practice, and structure. They use negative adjectives (e.g., poor, low-class, with subsistence needs, uneducated, dispossessed, and uncommitted) reflecting the vulnerability of the pajareros in front of authorities. However, officers also use positive adjectives (e.g. resource knowledgeable, organized, participatory, understanding) countering the negative assessment and reinforcing their requests to use SOB. Other opinions about

\footnotetext{
3 Information obtained directly from a review of the reports of the $2012-2013$ seasons.

4 That is, regulated by Article 51 of LGVS.

5 In the Mexican Official Standard nom-059-Semarnat-2010, species are listed based on risk categories.
} 
the pajareros describe them as peasants, traditional, suspicious, critical, persistent, and assertive.

But public officers did recognize the pajareros face several adverse situations including poverty, hunger, and stigmatization -mostly from radical environmentalists- as "bad people." Examples of this vilification are a newspaper article entitled "Parrots in the clutches of the smugglers" (Gómez-Quintero 2007) and campaigns using comics and stories (e.g. Cantu et al. 2010) displaying the sellers as evil people. Even some biologists and other scholars perceive pajareros as criminals (e.g. Sosa-Escalante 2011). In Mexico as in other countries worldwide (Roldán-Clarà et al. 2014) this aversive attitude might relate to public ignorance about SOB use being an ancient local cultural activity, and to lack of recognition of SOB as pets.

The interviewees mentioned pajareros feel intimidated by assuming the government fails to explicitly inform them of capture of SOB being legally allowed. According to officers' responses, pajareros view SOB use permit authorization as an imposition and feel contempt for the process itself. Interviewees mentioned pajareros are dissatisfied with the required paperwork, which they consider to be unfair to them. The feelings of dissatisfaction and subjugation of pajareros might emerge from sudden fast changes suffered by the applying legislation. Robles de Benito (2010) stated that rural people have insufficient time to adapt to changes in emerging centralized policy, especially because they are seldom considered when regulations are modified.

\section{Determination of harvest rates}

One of the interviewed officers referred to determination of harvest rates as sort of tugof-war: "[...] It is a little like a race between what they [the pajareros] need and demand, and what we can decide based on reasonably reliable information [...]." None of the interviewees explained what exactly that meant, but we identified legislative, environmental, social, and economic criteria used for assigning harvest rates to pajareros. In the following sections we examine each of these four criteria, beginning with the legislative criteria.

Officers repeatedly referred to decisionmaking as based on the legal framework mainly on specific articles of the LGVS, but also taking ecological criteria into account. They mentioned that for 15 years they have held annual meetings with CONABIO staff to decide which species are susceptible of being used and what number of birds can each catcher capture ${ }^{6}$. Within the ecological criteria, emphasis is placed on the population studies ${ }^{7}$ carried out by CONABIO to support harvest rate determinations. We understand that any program designed to regulate the exploitation in a sustainable way requires periodic population size estimates, as was also assumed by Johnson, Walters, and Scott (2012) and Sodhi et al. (2011). According to the interviewees, population size is considered for establishing harvest rates. If the population is large, then "nothing happens," as mentioned by an interviewee: "[...] if there are 40 million Northern Cardinals, and 3 thousand are captured per year, nothing happens. That is not a problem for the population. A greater number of birds are killed by cars or due to collisions with

\footnotetext{
${ }^{6}$ As mentioned in the Procedure Manual related to the conservation, management and sustainable use of wild fauna and flora and other biological resources: "Those interested in obtaining permits for the capture of SOB outside UMA can request it to the Ministry exclusively via his Federal Delegation in the State in which the permit will allow the capture".

${ }^{7}$ In Section II of Article 108 of LGVS standards is mentioned that the Ministry will apply criteria of training, which consist of the specific measures for the conservation of wildlife and its habitat such as the development of population studies.
} 
radio and television antennas [...]." Interviewees from Semarnat and CONABIO coincided in the sustainability of subsistence use, because of it being a small-scale activity. Based on this statement, the quantities to be used can be underestimated when population size is recognized as being "large."

Respondents accounted that before the adoption of the LGVS (DOF 2000) ${ }^{8}$ subsistence permits were assigned without the aid of any technical data about population sizes -as stated by Iñigo-Elias, Rosenberg, and Wells (2002)- and that far more species were then authorized ${ }^{9}$, the number of permitted species becoming restricted by subsequent administrations. For example, in the period 1997 - 1998 permits were granted for 78 species of SOB (López-Medellín 2003). However, interviewed officers sustained that harvest rates are nowadays based on technical population assessments. Population size of $\mathrm{SOB}$ is estimated by CONABIO, in some states every 2 years. In the Final Report of the Evaluation, Monitoring and Determination of Harvesting Limits to the Use of Song and Ornamental Birds for Subsistence (Final Report 2012) based on fieldwork conducted in 2011 and prepared by CONABIO, were chosen State of Mexico, Michoacán, Morelos and Veracruz. Pajareros can propose species of their interest to be assessed. The fieldwork consists of a visit of CONABIO staff in coordination with the pajareros to sites previously chosen based on occurrence of the highest number of authorized species to be captured $^{10}$ and in sites newly suggested or previously used by pajareros. Once the data from these field surveys has been analyzed, CONABIO submits a final report to the DGVS, the aforementioned Final Report (2012). Respondents recognize some uncertainty issues in these studies, because estimates are based on scarce data. Additionally, there is also uncertainty regarding budget availability for continuation of studies during future years: which despite the relevance given to such studies can be a serious problem that characterizes an inconsistency in proper management of subsistence use.

One interviewee mentioned CONABIO also uses foreign documents and studies such as the Audubon Watchlist 2007 Species, the Migratory Bird Treaty Act, and the North American Breeding Bird Survey (NABBS) to support decision-making regarding harvest rate assignments. However, that use requires caution -especially for harvest permit assignmentbecause these documents basically contain information about birds in North America, while most of the used SOB are captured in central and southern Mexico where some species are endemic or semiendemic (Johnson et al. 2012), and therefore absent from such literature.

We concluded that assignation by officers of harvest permits also depends in geographical areas, some states having none or fewer subsistence SOB permits than others. The online documentation of the DGVS (2012 DGVS) includes only 16 of the 32 states in which subsistence SOB use is permitted (Aguascalientes, Coahuila, Durango, Estado de México, Guanajuato, Hidalgo, Jalisco, Michoacán, Morelos, Nayarit, Nuevo León, Puebla, Querétaro, San Luis Potosí, Sinaloa, and Veracruz) and Article 67 of the SOB Calendar for the 1998-

\footnotetext{
8 They were given through the Calendars of Song and Ornamental Birds (see DOF 1998).

${ }^{9}$ For example, in Article 58 of the Agreement establishing the hunting and SOB use Calendar for the 1998-1999 season, the capture of 81 species was authorized.

${ }^{10}$ As mentioned in the Final Report (2012) which says that: "the states were chosen based on [as a first criterion] the higher rates of SOB use in the mode of subsistence during the period $2003-2006 "$.
} 
1999 period harvesting of SOB prohibits capture in seven states. Because SOB harvest rates were estimated based on capture demand before the LGVS entered in force -a time described as "when there was no information," - we interpreted the number of capture applications within the economic criteria. Then, if for some reason there are not population studies of a requested species, one might assume that they will also use this criterion. The number of applications for this activity is not homogeneously distributed among Mexican states, some having numerous bird catchers and others very few. Finally, the social criterion contemplated by officers was expressed by one of the interviewee's statements: "applicants are listened to;" however, responses to interviews emphasized legal and ecological criteria over social criteria.

\section{Relationships between government officers and other stakeholders}

The accounts about the relationships of interviewed government officers with pajareros and their associations includes previously mentioned annual meetings of pajareros with DGVS staff usually held in April or May at the request of the own pajareros, or sometimes of the DGVS. Occasionally meetings turn chaotic because all the pajareros make claims and all want to express their points of view. At these meetings, the pajareros are listened to and certain issues are negotiated, but the authority has the final decision. Officers mentioned several topics covered in the meetings: (1) harvest rates and bird species that the pajareros can use or not, (2) information from CONABIO, (3) future needed monitoring, (4) information from the pajareros, and (5) the problems encountered with different authorities by pajareros. Likewise, workshops organized by the DGVS and Profepa are held for instructing users on how to fill out a note or invoice and about bird bands. Finally, as mention earlier, pajareros and CONABIO interact in population studies in which pajareros can propose the sampling sites and act as guides.

All officers interviewed feel that the relationship with pajareros and their associations during meetings, workshops, and field studies is good and respectful, a positive notion that reflected in several testimonies, and that suggests the existence of a productive, diversified, and positive collaboration between managers and stakeholders including direct users of the resource. We think this is an excellent strategy since the wildlife management process improves when commitments are shared and when all stakeholders collaborate (Decke et al. 2012; Mortenson, and Krannich 2001). In addition, involvement of the pajareros in the management process increases the chances of them consenting with DGVS decisions (Mortenson, and Krannich 2001).

\section{Officers' perception of their work}

Our analysis of responses to interviews leads us to surmise that DGVS officers have a proactive and holistic view, i.e., they make decisions taking into account the feedback and opinions of experts from different disciplines. In particular, they consider that use of natural resources can become a method of conservation and generation of economic resources. A recent report about wildlife trade in Latin America from the United Nations Environment Programme (2017) mentions that wildlife trade can stimulate habitat conservation through the 
revenues it generates, but it needs adequate management practices that results in positive livelihood and ensures the sustainable use.

Also, the role of the DGVS is multidimensional and focused on the three pillars of sustainability (environmental, economic and social) as much as in its legal framework. As mentioned above, when the DGVS faces a dilemma the legal framework is preferred and the social aspects are neglected. Mortenson and Krannich (2001) comment that the fear of weakening authority, the lack of training in social evaluation, the tendency to avoid conflicts, and undervaluation of the human dimension as a body of legitimate knowledge are among the crucial impediments for taking into account the human dimension in the management of natural resources. CONABIO plays the technical role in the case of environmental aspects. CONABIO officers think that it is important to analyze case-by-case considering many factors beyond use, including deforestation and fragmentation of habitat, among others. According to DGVS officers there is collaboration with CONABIO in the decisionmaking process, but CONABIO officers affirm that decisions are made by the DGVS "behind closed doors." We observed a slight discrepancy in the role of CONABIO in terms of the varied degree of involvement perceived by interviewees in decisionmaking about harvest rates. The DGVS gives greater weight to CONABIO, but officers from that institution perceive that CONABIO has a lesser degree of involvement than that recognized by DGVS officers; therefore lack of communication is apparent between both public institutions regarding this issue.

Officers expressed differences and similarities between use in UMAs and subsistence use. UMAs are private properties registered by the government in which SOB are used in a "sustainable" way, the meaning of sustainable remaining vague. In addition, one of the fundamental ideas about UMAs is that "the owner of the land values what she or he has." Officers express a positive evaluation of the UMAs and a negative appraisal of the subsistence system, which is considered as "unregulated" (Figure 1), considering that the pajareros should switch from traditional subsistence use to SOB management within UMAs. Similarly, Article $9^{\circ}$ of the LGVS mentions that it corresponds to the Federation "the promotion (...) of the establishment of UMAs". This recommendation for pajareros is based on the present legislation encouraging the UMAs system. Nine articles of the LGVS are devoted to the UMAs (39-47), but only two (92 and 93) are dedicated to subsistence use. As could be expected, the officers from the DGVS and CONABIO have an institutional perspective, their objectives being to promote and prioritize UMAs (Benito Robles 2010). For example, the 4.2 strategy of the preceding National Development Plan (2007-2012) proposed to increase the surface area of the UMAs. One of the interviewees said that initially the associations were committed to develop SOB use in UMAs in order to generate higher incomes for all pajareros. Despite the enforcement to increment UMAs, this initiative did not prosper, as mentioned in the Song and Ornamental Birds Type Management Plan (Semarnat 2009), and many more permits are granted for subsistence use than for use in UMAs (CruzRomo, and Olivera de Ita 2011; LopezMedellin, and Iñigo-Elias 2003). Additionally, the subsistence system is considered incompatible with the UMAs system, 
because pajareros are dispossessed, i.e., they do not own land or belong to an ejido ${ }^{11}$. Therefore there is a contradiction between what is proposed in the development plans (containing part of what is institutionally desired) and what officers may actually execute or consider more convenient. If the present legal situation adjusts to the pajareros ancestral knowledge about SOB catching, care in captivity, trade, and religious values (Roldán-Clarà et al. 2016 in press), institutions should improve the subsistence use system outside UMAs. Nonetheless, officers do recognize a public debate issue exists regarding the operation of the UMAs system and the scope of management plans. For example, several researchers report the failure of UMAs registration to assure that the government designs and implements appropriate conservation strategies, makes accurate estimates of populations, and reports and monitors their functioning (García-Marmolejo et al. 2008; Sisk et al. 2007; Valdez et al. 2006; Weber et al. 2006). In addition, Valdés-Alarcón and Segundo-Galán (2011) state that the small size of UMAs is insufficient for achieving the goals of habitat conservation. Again, we must point out the seeming contradiction existing between what

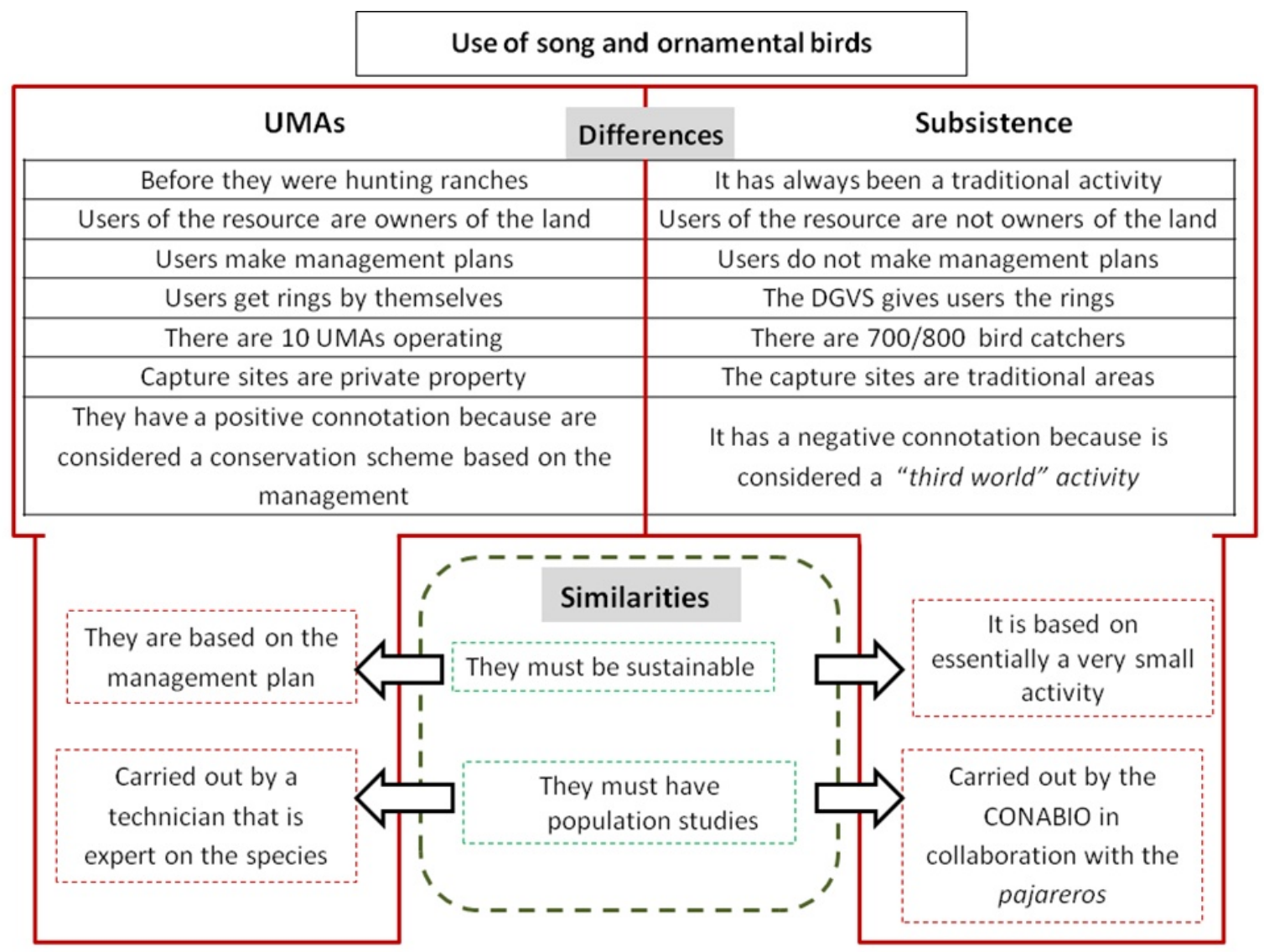

Figure 1. Interpretation of the differences and similarities between the extensive UMAs and the use for subsistence according to interviewees. Abbreviations: DGVS: General Wildlife Office, UMAs: Management Units for the Conservation of Wildlife, CONABIO: National Commission for the Knowledge and Use of Biodiversity.

\footnotetext{
11 This is already mentioned in the introduction of the Song and Ornamental Birds Type Management Plan.
} 
the environmental policy aims to promote and what environmental officers execute and consider more appropriate; therefore, environmental policy agents and development planners pay little attention to their officers' experience.

\section{Problems detected}

In addition to above-mentioned issues, interviewees noticed other problems affecting SOB use. Interviewees agreed in the insufficient training of staff of present and past administrations, some officers having limited capacity for decision-making; a problem previously noticed by Weber et al. (2006). An officer revealed occasional lack of transparency, so that the arguments and reasons involved in making and implementing decisions are unclear. Another problem is the short time available for decision-making due to deadlines for responding to applications, as mentioned in the Song and Ornamental Birds Type Management Plan (Semarnat 2009). The interviewees also mentioned deficiencies in inspection and surveillance made by Profepa because of insufficient staff and budget, therefore being opportunistic, inconsistent, and fall short from the desired goals. An officer explained the police also make inspections and surveillance (article 105 of the LGVS), but police officers are unprepared for the task ${ }^{12}$. Moreover, an interviewee mentioned cases of police officers chasing pajareros without them committing any crime.

The frequent detection of sale of free DGVS documents by leaders of the pajareros' associations was related by interviewees, one of them mentioning leaders exploit and take advantage of their associates while receiving rewards from the social strength of the organization. Other authors in Brazil (Souza and Soares-Filho 2005 cited in Alves et al. 2010) mention that bird catchers and small sellers are exploited by mayor traders, however, in the recent Mexican study (Roldán-Clarà et al. 2017), this was not detected. Another Mexican officer claimed that pajareros abuse of the term "subsistence," some of them having additional economic income. They also abuse the notion of "tradition" to justify permit applications. The problem of the noncompliance with the law is often mentioned in the interviews and several officers mentioned persistent and frequent illegal and unreported use. Some interviewees explained ways how frauds are perpetrated: in some cases, bird catchers have residence and capture birds in two different states; in other cases, many birds do not carry bands, which are kept by bird catchers; and if they do band captured birds, remove the bands before selling them.

Because of all of the above-mentioned issues, officers recognized the existing debate and controversy about the use of SOB for subsistence purposes, some people -former officers of Semarnat and NGOwanting its proscription. Other authors recognized that subsistence use of birds is the most nationally and internationally discussed topic (Cruz-Romo, and Olivera de Ita 2011). Sosa-Escalante (2011) mentioned that some permits could protect illegal specimens. Although it is argued that the use of birds should be done in a non-extractive way, i.e. through birdwatching ecotourism -a kind of use some authors consider to be the best alternative for bird catchers (Cantú et al. 2011) - the main challenge being linking the pajareros with ecotourists.

Based on officers' descriptions of problems, it seems they have a good idea of

\footnotetext{
12 Although in the Article 139 of the LGVS mentions: "the Ministry will promote the training in the terms of wildlife of staff involved in inspection and surveillance activities (...)".
} 
the difficulties they face; however, we did not ask officers if they had any proposals for improving this situation. The problematic is complex and maybe co-management (Berkes 2009) or adaptive management (Williams, and Brown, 2014) would help finding solutions.

\section{Most controversial regarding SOB use}

The most contentious issue expressed by officers is the convenience of the ban on parrots, because article 60 Bis 2 of the LGVS published in October 2008 prohibits the use of Mexican psittacines. All officers argue that the ban does not preserve the species and doubt of its usefulness because: (1) the birds are still captured for being considered a plague, (2) the resource is wasted, (3) the forest is cut down because of economic reasons despite capture of birds would provide an economical alternative for farmers, and (4) the breeders of macaws and other psittacines who have spent years reproducing them legally are severely affected. A study reported similar cases among Mexican (Aldana et al. 2006) and Colombian farmers (Cruz-Romo, and Olivera de Ita 2011), and we found comparable statements made by public officers in the Mexican newspaper El Universal (15 August 2010). Cooney and Jepson (2006) hold a similar opinion and argue that the ban is difficult to implement because it leads to increased demand. It can also be counterproductive because it generates incentives for illegal trade since the price of the prohibited specimens increases. These and other authors even add that prohibiting the use of SOB can alter cultural practices valued by people and worthy of preservation, suggesting that the solution could be to establish a more sustainable and equitable wildlife market instead of unanimously forbidding all wildlife trade (Jepson, and Ladle 2005). This sustainability could be achieved through certificates issued by Semarnat (DOF 1988, LGEEPA, Art. 77 Bis, fracc. V) -as suggested in Indonesia (Kristianto and Jepson 2011)- establishing standards raising the economic value of individual birds (e.g., good quality of song; Jepson et al. 2011), and because they were captured respecting certain guidelines (e.g. only by traditional means by well-organized catchers from small communities).

Other arguments support parrots and other bird bans, for example, it is argued that the total ban is easier to implement for the responsible staff, deters smugglers, changes the attitude of consumers reducing the demand, reduces the extractive use hampering non-extractive ones such as birdwatching, and claims of little evidence that wildlife use incentives habitat protection (Cantú et al. 2011; AOU 1991). There are conflicting opinions regarding the ban, but debating issues of bird use is beneficial by generating discussion maybe leading to urgently needed system improvements (Jepson, and Ladle 2005). We believe that continuation of subsistence permits is necessary because SOB use is part of the Mexican biocultural heritage (Toledo et al. 2010). While all arguments are justifiable, they reflect the pros and cons of current regulations and contribute to improve governance of wildlife management (Decker et al. 2012) because more stakeholders participate with their opinion about resource management.

\section{CONCLUSIONS}

Our results make us believe that decisionmaking about SOB use is less vertical than was expected since we perceived some 
level of direct participation of the associations, their leaders, and the pajareros. Therefore, our initial hypothesis was not fulfilled; the decision-making system does not have an authoritarian approach, but rather a passive-receptive one where managers listen to the concerns of stakeholders. However, much is needed to reach a horizontal relationship. Even though officers consider the pajareros vulnerable, they also recognize positive qualities in them. This empathy will allow minimization of identified problems when working together to find solutions in a co-management or adaptive management scheme. The opinions of the four officers related to the commercial activity of SOB reveal they have a deep knowledge of problems concerning SOB use. We also recognized that the institutional discourse about transforming the subsistence into the UMAs system is inconsistent with the social reality of the pajareros. Harvest rates are decided based on legislative, environmental, social, and economic criteria, and although in their speech officers privilege legislative and ecological criteria, as scholars we know that databases and population studies are insufficient and inappropriate. It is important to increase links between the academy and government officers for performing more studies of the most demanded species, such as the Slate-colored and Brown-backed Solitaires. Officers are against the standing parrots ban and recognize the existing social controversy. This is a research topic per se and is of great interest for communicology and social anthropology. Finally, the obvious limitations of or study makes us suggest further steps, more work being needed. It would be interesting to see how the pajareros feel about officers opinions and SOB use management and to compare our results with answers given by pajareros.

\section{ACKNOWLEDGEMENTS}

This work could not have been possible without the collaboration of interviewed people. We acknowledge Silvia Espejel and Sergio Zárate for translating the manuscript. Chester Zoo, Loro Parque, Idea Wild, and the Consejo Nacional de Ciencia y Tecnología (CONACyT) financed the project. Special thanks to Universidad Autónoma de Baja California (UABC), where the first author study her PhD. Finally we thank the anonymous reviewers for reviewing the manuscript.

\section{REFERENCES}

Albuquerque UP, Lucena RFP, Freitas EM, Neto $L$ (2014a) Selection of Research Participants. In: Albuquerque UP, Cunha LVFC, Lucena RFP, Alves RRN (eds) Methods and Techniques in Ethnobiology and Ethnoecology. 1 ed. Springer, New York, pp. 1-14

Albuquerque UP, Cunha LVFC, Lucena RFP, Alves RRN (2014b) Methods and Techniques in Ethnobiology and Ethnoecology. 1 ed. Springer, New York.

Albuquerque UP, Ramos MA, Lucena RFP, Alencar NL (2014c) Methods and Techniques Used to Collect Ethnobiological Data. In: Albuquerque UP, Cunha LVFC, Lucena RFP, Alves RRN (2014b) Methods and Techniques in Ethnobiology and Ethnoecology. 1 ed. Springer, New York. pp.15-38

Aldana NJ, Díaz-Porres M, Feijoo AM, Constanza-Zuñiga M (2006) Valoración del uso de la fauna silvestre en el municipio de Alcalá, Valle del Cauca. Scientia Et Technica XII 291-296.

Alves RRN, Nogueira E, Araujo H, Brooks S (2010) Bird-keeping in the Caatinga, NE Brazil. Human Ecology 38:147-156.

Alves RRN (2012a). Relationships between fauna and people and the role of ethnozoology in animal conservation. Ethnobiology and Conservation 1:1-69. 
Alves RRN, Lima JRdF, Araujo HFP (2012b) The live bird trade in Brazil and its conservation implications: an overview. Bird Conservation International 23 (1): 53-65.

Alves RRN, Rosa IL (2013) Animals in Traditional Folk Medicine: Implications for conservation. 1 ed. Springer. New York

Alves RRN, Souto WMS ( 2015) Ethnozoology: A Brief Introduction. Ethnobiology And Conservation 4:1-13.

Andréu-Abela J (2001) Las técnicas de análisis de contenido: Una revisión actualizada, Centro de Estudios Andaluces.

Belda A, Peiró V, Seva E (2012) The relationship between plants used to sustain Finches (Fringillidae) and uses for human medicine in southeast Spain. Evidence-Based Complementary and Alternative medicine 2012: 1-13.

Berkes F (2009) Evolution of co-management: Role of knowledge generation, bridging organizations and social learning. Journal of Environmental Management 90: 1692-1702.

Bezerra DMM, Araújo HFP, Alves ÂGC, Alves RRN (2013) Birds and people in semiarid northeastern Brazil: symbolic and medicinal relationships. Journal of Ethnobiology and Ethnomedicine 9:1-11

Bezerra DMM, Araujo HFP, Alves RRN (2012) Wild birds as source of food in the semi-arid region of Rio Grande do Norte State, Brazil. Sitientibus Série Ciências Biológicas 11:177-183.

Mascia MB (2005) Discrepancies in Reported Levels of Wildlifelnternational Wildlife Trade. Conservation Biology 2020-2025. Conservation Biology 28(3): 663-676.

Burivalova Z, Lee TM, Hua F, Lee JSH, Prawiradilaga DM, Wilcove DS (2017) Understanding consumer preferences and demography in order to reduce the domestic trade in wild-caught birds. Biological Conservation 209: 423-431

AOU (American Ornitologist' Union), Bird Trade Subcommitttee of the American Ornithologist' Union (AOU) Conservation Committee (1991) The conservation crisis: International trade in live exotic birds creates a vast movement that must be halted. The Auk 982-984.

Cantú JC, Sánchez ME, Aviles CR (2010) ¡Agárrenlo que es ratero! Defenders of Wildlife, Mexico DF.
Cantú JC, Gomes de Silva H, Sánchez ME (2011) El Dinero vuela. El valor económico del ecoturismo de observación de aves. Defenders of Wildlife, Washington dc.

Cooney R, Jepson P (2006) The international wild bird trade: what's wrong with blanket bans? Oryx 40: 18-23.

Cruz-Romo L, Olivera de Ita A (2011) Conceptos ecológicos, métodos y técnicas para la conservación y aprovechamiento de aves canoras, de ornato y psitácidos. In: Sánchez Ó, Zamorano P, Peters E, Moya H (eds) Temas sobre conservación de vertebrados silvestres en México. Secretaría de Medio Ambiente y Recursos Naturales, Instituto Nacional de Ecología. México DF, pp. 121-148.

Decker DJ, Riley SJ, Siemer WF (2012) Human Dimensions of Wildlife Management. The Jonhns Hopkins University Press. Baltimore, Maryland.

De la Cruz M F, Vázquez-Dávila MA, Jerez MP, Montaño EA C, Villegas YA (2014) Aves silvestres y domésticas de los Chontales de San Andrés Tlahuilotepec, Distrito de Yautepec, Oaxaca, México. In: VázaquezDávila MA (Ed) Aves, personas y culturas. Estudios de Etno-ornitología 1.CONACYT/ITVO/Carteles Editores/UTCN. Oaxaca, México, pp.169-186

DGVS (Dirección General de Vida Silvestre) (2012) Época hábil para el aprovechamiento de aves canoras y de ornato para fines de subsistencia en la temporada 2013-2014. [http://www.semarnat.mx/temas/gestionambiental/vida-silvestre/aprovechamiento-deaves-canoras-y-de-ornato-para-fines-de] Accessed 5 March 2014.

DOF (Diario Oficial de la Federación) (1988) "Ley General de Equilibrio Ecológico y Protección al Ambiente". 30-08-2011.

DOF (Diario Oficial de la Federación) (2000) "Ley General de Vida Silvestre", 07-06-2011.

DOF (Diario Oficial de la Federación) (2007) "Plan Nacional de Desarrollo 2007-2012", Gobierno de los Estatados Unidos Mexicanos. Poder Ejecutivo Federal, D.F.

DOF (1998) Manual de procedimientos para autorizaciones, permisos, registros, informes y avisos relacionados con la conservación, manejo y aprovechamiento sustentable de la flora $y$ fauna silvestres y otros recursos biológicos. Gobierno de los Estatados Unidos Mexicanos. Poder Ejecutivo Federal, D.F. 
Dowsett-Lemaire F, Wilson JGM, Medland RD Roxburgh L (2015) Excessive Bird Collecting In Malawi: A New Threat. Bird Conservation Internation 25, 259-269.

Drews C (2001) Wild animals and other pets kept in Costa Rican households: incidence, species and numbers. Society \& Animals 9:(2): 107-126.

Fernandes-Ferreira $\mathrm{H}$, Mendonça SV, Albano C Ferreira FS, Alves RN (2012) Hunting, use and conservation of birds in Northeast Brazil. Biodiversity and Conservation 21: 221-244.

García-Marmolejo G, Escalona-Seguram G, Van Der Wal H (2008) Multicriteria Evaluation of Wildlife Management Units in Campeche, Mexico. The Journal of Wildlife Management 72, 1194-1202.

Gobbi J, Rose D, De Ferrari G, Sheeline L (1996) Parrot smuggling across the Texas-Mexico border. Washington DC: Traffic USA.

Gómez-Álvarez G, Teutli SC, Reyes G SR, Valadez RA (2005) Pájaros y otras aves utilizadas como animales de ornato y compañía. AMMVEPE 16(5):129-139.

El Universal (2007) Pericos en las garras de los contrabandistas. México: El Universal Diciembre 16, 2007

Hernández Sampieri, Fernández Collado, Baptista Lucio (2007) Metodología de la Investigación. MCGRAW-HILL. Montreal, Canadá.

International Society of Ethnobiology (2006) International Society of Ethnobiology Code of Ethics. http://ethnobiology.net/code-of-ethics/. Accessed 20 Jul 2013.

Iñigo-Elias EE, Ramos MA (1991) The Psittacine trade in Mexico. In: Robinson JG, Redford $\mathrm{KH}$, Neotropical wildlife use and conservation. The University of Chicago Press. Chicago and London, pp. 380-392.

Iñigo-Elias EE, Rosenberg KV, Wells JV (2002) The Danger of Beauty. Birdscope 1-4, New York: Cornell Lab of Ornithology.

Jepson P, Ladle RJ (2005) Bird-keeping in Indonesia: conservation impacts and the potential for substitution-based conservation responses. Oryx 39: 1-6.

Jepson P, Ladle RJ, Sujatnika (2011) Assessing market-based conservation governance approaches: a socio-economic profile of Indonesian markets for wild birds. Oryx 45: 482-491.
Johnson F, Walters M, Scott Boomer G (2012) Allowable levels of take for the trade in Nearctic songbirds. Ecological Applications 16(4): 236-243.

Kristianto I, Jepson P (2011) Harvesting orange-headed thrush Zoothera citrina chicks in Bali, Indonesia: magnitude, practices and sustainability. Oryx 45: 492-499.

Lenzen M, Moran D, Kanemoto K, Foran B, Lobefaro L, Geschke A (2012) International trade drives biodiversity threats in developing nations. Nature 486: 109-112.

Leong KM, Emmerson DP, Byron R (2011) The New Governance Era: Implications for collaborative conservation and adaptive management in Department of the Interior agencies. Human Dimensions of Wildlife 6: 277-290.

Licarião MR, Bezerra DMM, Alves RRN (2013) Wild birds as pets in Campina Grande, Paraíba State, Brazil: An Ethnozoological Approach. Anais da Academia Brasileira de Ciências 85:201-213.

Li L, Jiang Z (2014) International Trade of CITES Listed Bird Species in China. Plos One 9(2): 1-8.

López-Medellín X, Iñigo-Elias E (2009) La captura de aves silvestres en México: Una tradición milenária y las estrategias para regularla. Biodiversitas 83: 11-15.

Marín-Espinoza G, Guevara-Vallera S, PrietoArcas A, Muñoz-Gil J, Carvajal-Moreno Y (2011). Comercialización ilegal de aves silvestres: un caso en Venezuela. The Biologist 9(1): 38-52.

Melink E, Jasso MG, Aguirre R (1988) Utilización de las aves de jaula silvestres en el altiplano potosino-zacatecano. Sobretiro de Agrociencia 71: 239-254.

Miles MB, Huberman AM (1994) Qualitative data analysis: an expanded sourcebook. SAGE Publications, London.

Mortenson K, Krannich RS (2001) Wildlife Managers and Public Involvement: Letting the Crazy Aunt Out. Human Dimensions of Wildlife 6: 277-290.

Navarro-Sigüenza AG, Rebón-Gallardo MaF, Gordillo-Martínez A, Peterson AT, BerlangaGarcía H, Sánchez-González LA (2014) Biodiversidad de aves en México. Revista mexicana de biodiversidad 85: 476-495. 
Piñuel-Raigada JL (2002) Epistemología, metodología y técnicas del análisis de contenido. Estudios de Sociolingüística 3: 1-42.

Pires S, Schneider JL, Herrera M (2016) Organized crime or crime that is organized? The parrot trade in the neotropics. Trends Organ Crim 19:4-20.

Reed MG, Henderson AE, Mendis-Millard S (2013) Shaping Local Context and Outcomes: The Role of Governing Agencies in Collaborative Natural Resource Management. Human Dimensions of Wildlife 18(4): 292-306.

Reuter A, Mosig P (2010) Comercio y aprovechamiento de especies silvestre en México: observaciones sobre la gestión, tendencias y retos relacionados. Traffic Norteamérica.

Robles de Benito R (2010) La estrategia de conservación, manejo y aprovechamiento sustentable de la vida silvestre. In: Durán $R$, Méndez M (eds) Biodiversidad y Desarrollo Humano en Yucatán, Mérida, by 427-431. Mérida: CICY, PPD-FMAM, CONABIO and SEDUMA.

Roldán-Clarà B, Lopez-Medellín X, Espejel I, Arellano $E$ (2014) Literature review of the use of birds as pets in Latin-America, with a detailed perspective on Mexico. Ethnobiology and Conservation 3: 1-18.

Roldán-Clarà B, Toledo VM, Espejel I (2017) The use of birds as pets in Mexico. Journal of Ethnobiology and Ethnomedicine 13:(35) 1-18.

Sahagún FB de (1969) Historia general de las cosas de nueva España. 2 ed. Numeration, Garibay AMK (annotations and appendices). Porrúa, México.

Semanart (1997) Programa de Conservación de la vida silvestre y diversificación productiva del sector rural: 1997-2000. Mexico City.

Semarnat (2009) Plan de Manejo Tipo: Aves canoras y de ornato. Dirección General de Vida Silvestre. Mexico D.F.

Silva Souto WM, Ribeiro Torres MA, Freitas Sousa BFC, Carvalho Lima KGG, LT Serra Vieira, Alves Pereira G, Guzzi A, Vieira Silva M, Nunes Pralon BG (2017) Singing for a cage: The Use and Trade of Passeriformes as Wild Pets in an Economic Center of the Amazon-NE Brazil Route. Tropical Conservation Science 10:1-19.
Sinovas P, Price B, King E, Hinsley A, Pavitt A (2017) Wildlife trade in the Amazon countries: an analysis of trade in CITES listed species. Technical report prepared for the Amazon Regional Program (BMZ/DGIS/GIZ). UN Environment - World Conservation Monitoring Centre, Cambridge, UK.

Sisk TD, Castellanos A, Koch GW (2007) Ecological impacts of wildlife conservation units policy in Mexico. Frontiers in Ecology and the Environment 5: 209-212.

Syker PW, Manfredi L, Padura M (2006) A brief report on the illegal cage-bird trade in southern Florida a potentially serious negative impact on the Eastern populations of painted bunting. North American Birds 60(2), 310-313.

Sodhi NS, Sekerciǒglu ÇH, Barlow J, Robinson SK (2011) Harvesting of Tropical Birds. In: Conservation of Tropical Birds, 1 ed. Blackwell Publishing Ltd. pp. 152-172.

Sosa-Escalante JE (2011) Aplicación de la ley para el combate del tráfico ilegal de vida silvestre en México: El caso de Charco Cercado. THERYA 2: 245-262.

Sosa MÁ (2010) Ahora, pericos y loros Ilegan de Sudamérica. El Universal. [http://www.eluniversal.com.mx/nacion/179723.ht $\mathrm{ml}$ Accessed 15 August 2010

South N, Wyatt T (2011) Comparing illicit trades in wildlife and drugs: an exploratory study. Deviant Behavior 32: 538-561.

SJ, Bogdan R (1984) Introducción a los métodos cualitativos de investigación. L'Hospitalet de Llobregat, Barcelona: Paidós Ibérica. Tidemann S, Gosler A (2010) Ethnoornithology: Birds, Indigenous People, Culture and Society. 1 ed. Earthscan/James \& James

Toledo VM (2003) Ecología, espiritualidad y conocimiento: De la sociedad del riesgo a la sociedad sustentable. Programa de las Naciones Unidas para el Medio Ambiente: Universidad Iberoamericana. México DF.

Toledo VM, Boege E, Barrera-Bassols N (2010) The biocultural heritage of Mexico: An overview. Langscape II: 7-13. 
Valdés-Alarcón M, Segundo-Galán M (2011) Estrategias de conservación en México para el borrego cimarrón (Ovis canadensis) y el berrendo (Antilocapra americana). In: Sánchez O, Zamorano P, Peters E, Moya H (eds) Temas sobre conservación de vertebrados silvestres en México, Semarnat, México DF. pp. 277-308.

Vásquez-Dávila A (2014) Aves personas y culturas. Oaxaca, México: Red de Etnoecología y Patrimonio Biocultural. 1 ed. CONACyT. Oxaca, Mexico.
Valdez R, Guzmán-Aranda JC, Abarca FJ, Tarango-Arámbula LA, Sánchez FC (2006) Wildlife conservation and management in Mexico. Wildlife Society Bulletin 34: 270-282.

Weber M, García-Marmolejo G, Reyna-Hurtado $R$ (2006) The tragedy of the commons: Wildlife management units in Southeastern Mexico. Wildlife Society Bulletin 34: 1480-1488.

Williams BK, Brown ED (2014) Adaptive Management: From More Talk to Real Action. Environmental Management 53. 465-479. 